\title{
Judging British Feminism from Pride and Prejudice
}

\author{
Shaobin Zhou \\ School of Foreign Languages, Xichang College, Xichang , 615000, China
}

\author{
Keywords: Jean Austen; Pride and Prejudice; Britain; feminism
}

\begin{abstract}
The novel Pride and Prejudice created by British novelist Jane Austen is a typical representative masterpiece of feminism, which described the equal social status and embarrassed life condition of the female in the then current British society. By shaping the new female image of the heroine Elizabeth, the author praised the good desire of the female at that time to pursue self-dignity and independent personality, expressed the female's rebelling and challenging to the traditional culture of make priority and marked that the females hunted for the feminism thought of self-liberation. Of course, the feminism thought of the author in this novel also had some shortcomings due to the limitation of development of times, but this does not influence its important enlightenment to the modern society.
\end{abstract}

\section{Introduction}

The British novelist Jean Austen in the $19^{\text {th }}$ century created a famous long novel Pride and Prejudice, which described a heroine called Elizabeth. In the then current social system where male was dominated, the female had neither social status nor the so-called right to speak. In order to change such unequal female status and living condition, the author reflected her own feminism thought through the unique narration method and writing contents in the novel, expressed her dissatisfaction and challenge to the male-oriented status distinctively and pursued the social status of equality between man and male and the freedom of marriage, and she is the spokesman of the new female image in the then current British society, with a strong ideological connotation of feminism.

\section{Source of feminism thought in Pride and Prejudice}

\section{Factors of times}

When the author created this novel, it was under the background that the capitalist system of Britain was not so perfect, and people still kept a lot of feudal in this mind, especially the traditional thought that women were inferior to men was still advocated by people, the female did not have any social status, and the male always occupied the core control status in the society and had the absolute authorization and status. In that situation, the female basically could not enjoy the normal social treatment, and could only exchange the so-called beautiful life through marriage, but actually, it turned out that the female depended on male excessively, further losing the right to speak. Therefore, in the Jean Austen's novel Pride and Prejudice, the property inheritance event of the couple Bennett was a powerful evidence. They did not have son, so their properties could be only inherited by their remote relatives and friends, and the female had no right of inheritance. This event showed that the female in the then current British society had no autonomy, losing the opportunity of independent survival and development. They were repelled and limited everywhere in the British society, and this stimulated the author's female status and ideal to pursue female awareness.

\section{Factors of author}

The feminism thought in this novel was also from the feminism concept the author herself owned. She was born on the British social condition with inequality between male and female, and had a deep understanding to the social phenomenon of inequality. At that time, she also had a low status and was suppressed, however, it was such life status that stimulated her to use literature creation to express her desire as female. She attempted to shape female and strived for her own right to speak 
and survival space through the new image of heroine in the literature works. Therefore, in her works, including Pride and Prejudice, there were texts and ideas to eulogize the female's awareness of subjectivity and right. In Austen's opinion, female should be equal with make, with the same intelligence and ability, and sometimes she even thought that female had more insight and analysis ability than male. Therefore, in Austen's works, female was lifted to the status of heroine, no longer the affiliate to male, but the female of new times with virtue, wisdom and rationality. Called by the ideal and rationality, they became an independent individual like male, and gradually completed the process of growth and maturity. Therefore, we say that Austen was a real feminist.

\section{Expression of the current British feminism in Pride and Prejudice}

\section{Narration skill of feminism}

Austen's novel Pride and Prejudice had a strong ideology of feminism, first reflected in her writing style. Austen adopted the relatively unique narration perspective and method. Compared with the traditional male perspective, she directly started from the perspective of female, spread the dialogue centered on female, reflecting the female's right to speak, and spread the narration of story based on this. Therefore, we say that this novel had the narration method of feminism, which was the ideological reflection of feminism, and boldly broke through the traditional male narration method, and took the female as the main figures of the figure, making female become the main body of life and own the same right to speak and other due rights with male. Then, how was her narration skill? First, she used the narration perspective of the third person skillfully, directly presenting the heroines in the novel in front of readers. Such narration perspective can make the female figures not limited by time an space, express their own opinions freely and present all experience of the female, so that the British social life could be displayed vividly. Such narration method of the third person also protected the female's rights and interests to some extent, being another expression method of feminism. Second, such female narration perspective of Austen also greatly challenged the male-orientation tradition in the British society, and she launched the female who had always been in the vulnerable state to the historical stage, it was a unique mode of discourse of female for the mode of discourse from the female perspective, making the female's protagonist identity displayed in the story plot everywhere, and presenting the strong thought of feminism. This was actually the central reflection of Jean Austen's feminism thought, and she deliberately made the female become leading role of the novel narration.

\section{Narration contents of feminism}

In this novel, Austen depicted a new female image Elizabeth and expressed her strong feminism thought through the description to this image. In the then current British society, Elizabeth was a female image with extreme rebelling awareness, who had extraordinary rebelling personality and independent female thought and new opinions. From her we can see all advantage of the new female in the then current British society, for example, beautiful, gorgeous, clever and witty, could master some active power for their own life and feeling and could pursue their own happy life.

First, in the novel, Elizabeth described by Austen was a new female with rebelling and challenge spirit, she was dissatisfied with the traditional male-orientation society, dared fight against it fiercely. The then current British society was a society with red tapes, various customs and rituals required the female to keep the so-called lady style. However, the heroine in the novel quite disliked this, thinking that these thoughts were backward and harmful to female. She did oppositely and boldly challenged these worldly rituals. Therefore, in the novel, Elizabeth appeared in the so called high-grade venue with a scruffy image when visiting her sick elder sister, and showed an attitude of disguising to the worldly people in the banquet of Mrs. Catherine. All these descriptions to Elizabeth in the novel showed that she had a strong feminism thought, being a representative figure of new female in the British society.

Second, in this novel, Austin also conveyed the strong feminism thought through the description of Elizabeth's concept to love and marriage. In Elizabeth's opinion, her love should be independently dominated and controlled by herself, she was no longer limited to the traditional love concept and female could have their own subject awareness of love and could pursue their own 
feeling life independently. Therefore, in Pride and Prejudice, Elizabeth completely abandoned the personality of endurance and submission of the traditional female, but thought that the happy marriage of female was from the self-awareness of love, and there should be a love basis of understanding, respect and equality with male. This love concept was not acceptable in the then British society, being the extreme challenge or rebelling to the traditional marriage and love concept. For example, Elizabeth in the novel showed an attitude of criticism and sarcasm toward her good friend Charlotte's marriage and love concept based on money and material, and rejected two love pursuers, she thought that the marriage must be based on the profound feeling, and not all materials could bring happy and successful marriage life to female. Therefore, in this novel, Austen fiercely criticized the love concept of material and money priority in the upper society of British society. The then British society took money as the leading factor of marriage, and female had no status in marriage. Just like the tragedy of Mr. Bennett, he had no female successors, while after he died, his female family members lead a hard life without fixed settlement, because in the then current, female could not inherit the material heritage. After obtaining the heritage, his male relative thought that he could propose to Elizabeth with abundant material basis, however, he was rejected by Elizabeth ruthlessly. However, the marriage between Collins and Charlotte was almost established on money, without any sense of love, and their marriage was the naked benefit marriage. However, facing such social status, Elizabeth was not moved, and she definitely refused the marriage based on money, thinking that marriage was very important, must be based on the love of both sides and she attempted to arouse the repositioning of female in the then British society to love and marriage, and advocated the male and female equal marriage based on love, actually this was the central reflection that female wanted to get rid of the money and marriage transaction in the traditional society.

Third, Austen in the novel also expressed her objection to the backward thought that female was inferior to male, thinking that female should have their own status in the society, highlighting the image of female in the British society and fully expressing the modern concept of female-male equality. Specifically, in the novel, Austen fiercely criticized the phenomenon that female was inferior to male in the British society from the unique narration perspective of female, expressed her strong dissatisfaction with the male-oriented system and attempted to win a seat for the female patriots in the vulnerable and edge state. This novel had a strong female equality consciousness, being a great exploration of female's searching for self-status in the then British society. Actually, most of the traditional English literature works took male as the experience and discourse subject and female was often in the state of being ignored. The female lost their own life experience and psychological feeling, and could be only ruled and suppressed by male. Then, in Pride and Prejudice, uncharacteristically, Austen created the literatures with male as the experience subject, she made the female perspective become the main mode of narration, and made the heroine Elizabeth as the witness of the story, so as to make Elizabeth become the feminism spokesman of the author herself. This novel emphasized the thought of male and female equality, thinking that the female in traditional society were not smart and witty, and sometimes even more foolish and stupid than female. In the heroine's opinion, both female and male had their own advantages and disadvantages, and female did not need to exchange the so-called social status by depending on male excessively.

In addition, Austen also expressed the strong desire of female's pursuit of individual independence in the then British society by shaping the individuality of Elizabeth. Elizabeth was an optimistic female with rebelling personality, who did not accept the traditional customs and etiquette, and also sniffed the traditional worldly practices, and even showed an optimistic attitude of calm response to the arrogant Misses. Therefore, compared with male as the representative of strength and success in the traditional society, it was obvious that Austen degraded the male figures by praising and improving the female image, so as to satirize the male-dominated society and finally attempted to overturn the feminism thought in the male chauvinism. She affirmed the existence value of male, shaped a failed Mr. Bennett, but a successful Elizabeth, who could pursue her own love and marriage without depending on male, and could refuse the material marriage, so as to realize the effective overturning and destruction to the traditional male image. 


\section{Limitation of feminism in Pride and Prejudice}

Although Austen expressed her brave and bold feminism thought in the novel, after all, she was still a female of middle class living in that historical background, while expressing her dissatisfaction to male-dominated society, she also encouraged the female stand out bravely to rebel and criticize the male-dominated system, expected to arouse the female's respect consciousness to their own status and decompose the thought of male chauvinism. However, while guiding the female to obtain free love right, marriage freedom and right of equality and independence, she also had some shortcomings in her feminism thought. She was in a period when the capitalist system of Britain was imperfect, without advanced thoughts and the male chauvinism thought and male-orientation trend still had a strong influence. Her expression of the positive female image through the novel works and her concern about the female rights and interests were acceptable, however, their influence still was adversely influenced and resisted by the male chauvinism culture, so that there still existed some negative elements in her novel. Just like in the novel, Austen limited the independent image of heroin to the family more, but did not put the female figures in a broader social scene to reflect their independent right and equal status. Therefore, we say that Pride and Prejudice was the representative masterpiece of Jean Austen's feminism thought, with a strong female consciousness; however, its limitation is also worth concerning, and we should mine the active feminism thought, so as to play active influence and enlightenment function to our modern female life.

\section{References:}

[1] Huang Jie, Analysis on Subject Consciousness of Heroine in Pride and Prejudice [J], 2011(7):104-105

[2] Liang Hui, Feminism in Film Pride and Prejudice [J] Journal of Jilin Institute of Chemical Technology, 2013(8):33-36

[3] Liu Chang, Interpretation of Feminism in Pride and Prejudice [J], Journal of Chengdu University (social science edition) 2009(4):42-43

[4] Meng Xia, Feminism Consciousness of Jean Austen and in her Pride and Prejudice [J], Times Literacy, 2011(1):146-147

[5] Shi Rui, Feminism Narration Analysis in Pride and Prejudice [J] Times Literacy, 2010(5):25-26 